\title{
Crayfish in Czech cultural space: the longest documented relationship between humans and crayfish in Europe
}

\author{
J. Patoka ${ }^{1, \star}$, B. Kocánová ${ }^{2}$ and L. Kalous ${ }^{1}$ \\ 1 Department of Zoology and Fisheries, Faculty of Agrobiology, Food and Natural Resources, Czech University of Life Sciences Prague, \\ Kamýcká 129, 165 21, Praha 6 - Suchdol, Czech Republic \\ ${ }^{2}$ Centre for Classical Studies at the Institute of Philosophy, Czech Academy of Sciences, Na Florenci 3, 110 00, Praha 1, Czech Republic
}

Received October 1, 2015 - Revised November 13, 2015 - Accepted November 14, 2015

\begin{abstract}
The crayfish is an interesting element of cultural history in many regions where this animal plays an important role through its exploitation by humans. The present study provides comprehensive insight into the relationship between humans and crayfish within the Central European regions of Bohemia and Moravia, collectively recognized as the Czech cultural space. The study combines data obtained from Czech and Latin historical literature; archival juristic documents and codes of law; old cooking and fishing journals, books, and textbooks; digitized materials available on the internet; and specialized and scientific publications. Human exploitation of crayfish within the evaluated region has been continuous from prehistory to the present and is thus the oldest in all of Europe. Important moments are displayed on timeline.
\end{abstract}

Key-words: Freshwater invertebrate / exploitation / history / aquaculture / Czech Republic

\begin{abstract}
Résumé - L'écrevisse dans l'espace culturel tchèque : la relation la plus longue documentée entre les humains et les écrevisses en Europe. L'écrevisse est un élément intéressant de l'histoire culturelle dans de nombreuses régions où cet animal joue un rôle important grâce à son exploitation par les humains. La présente étude offre un aperçu complet de la relation entre les humains et les écrevisses dans les régions d'Europe centrale de Bohême et de Moravie, collectivement reconnues comme l'espace culturel tchèque. L'étude combine des données obtenues à partir de la littérature tchèque et historique latine; de documents d'archives juridiques et de codes de la loi ; de vieux journaux, livres et manuels de cuisine et de pêche; de documents numérisés disponibles sur l'Internet; et de publications spécialisées et scientifiques. L'exploitation humaine des écrevisses dans la région étudiée a été continue depuis la préhistoire jusqu'à aujourd'hui et est ainsi la plus ancienne de toute l'Europe. Les moments importants sont affichés sur un tableau chronologique.
\end{abstract}

Mots-clés : Invertébrés d'eau douce / exploitation / histoire / aquaculture / République Tchèque

\section{Introduction}

Crayfish species are commonly exploited and often important cultural elements in all places where they occur and so understanding the relationships between human societies and crayfish would be relevant to better know the both societies and crayfish.

The cultural history of crayfish is interesting both from historical-anthropological and ecological views. Interestingly, the multidisciplinary approach using historical data may help to clarify management problems and conflicts in conservation biology (Clavero et al., 2015). Traditional relationship between humans and crayfish in Europe have been scarcely analyzed based on fragmented historical realia in just two previous studies (Swahn, 2004; Koutrakis et al., 2009). Although the crayfish is a known and popular animal in many regions,

\footnotetext{
* Corresponding author: patoka@af.czu.cz
}

detailed information on ancient and even modern crayfish exploitation put into context is usually not very accessible to biologists and thus is mostly overlooked. To better understand the relationship between human society and crayfish, we have compiled zoogeographical, linguistic, archaeological, and historical evidence from prehistory to the present from Moravia and Bohemia within the Czech cultural space.

\section{Study area}

The evaluated inland region in Central Europe comprises two historically well-defined territories: Bohemia in the west and Moravia in the east. The limits of the region are broadly defined by a series of mountain systems, such as the Bohemian Forest, Ore Mountains, Sudetes, and Western Carpathians. The region has an Atlantic-continental type of moderate climate and is situated on the borders of three 
European watersheds: the North Sea (Elbe River), Baltic Sea (Oder River), and Black Sea (Danube River) (Dvorak et al., 1997). The territory has been part of various historical political entities: the Duchy of Bohemia, the Kingdom of Bohemia, the Austro-Hungarian Monarchy, Czechoslovakia, the Protectorate of Bohemia and Moravia, Czechoslovakia again, and from 1993 to the present the Czech Republic (Pánek and Tuma, 2009).

Two species of crayfish are indigenous to the studied territory: (i) Astacus astacus (L.) in both Bohemia and Moravia; and (ii) Austropotamobius torrentium (Schrank) in Bohemia (Elbe River basin). Three species of crayfish are nonindigenous: (i) Astacus leptodactylus Eschscholtz imported in 1890s from the eastern part of Europe (Eastern Galicia) in order to replenish the declined native populations of $A$. astacus; (ii) North American Orconectes limosus (Rafinesque) which was first recorded in Europe in 1890 and subsequently has spread over the evaluated territory in about 1960; and (iii) North American Pacifastacus leniusculus (Dana) imported to the evaluated territory from Sweden in the 1980s (Kozák and Policar, 2003; Petrusek et al., 2006; Kouba et al., 2014).

\section{Results}

Information about crayfish was obtained from Czech and Latin historical literature deposited in libraries and archives; archival juristic documents and codes of law; old cooking and fishing journals, books, and textbooks; digitized materials available on the website of the Institute of the Czech Language of the Czech Academy of Sciences (in the Vokabulár webový (Web Dictionary section); card files of the Lexicon latinitatis medii aevi Bohemorum (Dictionary of Medieval Latin in the Czech Lands) available at the Centre for Classical Studies at the Institute of Philosophy of the Czech Academy of Sciences; as well as specialized and scientific publications.

\subsection{Prehistoric use of crayfish: archaeological evidence}

The earliest archaeological evidence of human crayfish consumption anywhere in the world was reported in the evaluated region and dated to the Neolithic, 4774-4500 BCE. That species was identified as $A$. astacus based on characteristics of excavated dactyl fragments (Patoka et al., 2014a). This fact is in accordance with the recent distribution of this species, which is indigenous to this area (e.g. Holdich et al., 2009; Kouba et al., 2014). Although we cannot definitely state whether crayfish consumption was common across the entire region, at least some inhabitants consumed them.

\subsection{The Middle Ages: manuscript evidence}

After the aforementioned archaeological finding, there is a long period with no reports of crayfish in Bohemia and Moravia. It is probably due to the absence of written sources since literary activity in the area did not begin until the second half of the 9th century. Nevertheless, there is no evidence supporting the assumption that crayfish were seen by inhabitants of Bohemia and Moravia in these times as cadaver scavengers and thus as inedible animals (as observed by Swahn, 2004, for ancient Greece and other cultures). Probably biblical food prohibitions (Leviticus 11: 42) had a more decisive role on public perceptions concerning crayfish consumption, added to the bad 'fame' as a scavenger.

We found crayfish mentioned in Bohemian sources written in both Latin and Old Czech in the Middle Ages. The first written record about crayfish here dates back to the 12th century, wherein the so-called Canon of Vyšehrad reports in his Latin chronicle on the interruption of the Sázava River's flow, followed by a watermill standing still in the dry river. The abbot and his monks from the adjacent monastery understood the river's interruption to be a miracle from God and they collected large fish and crayfish from the dry riverbed (CosmCont I, p. 234: "magnos pisces et cancros in sicco fundo collegerunt"). Unfortunately, the Canon does not mention what was done with the collected animals. One nevertheless can draw conclusions about the possible ways crayfish were used from information in following written Bohemian sources.

Crayfish are mentioned in works written by the group of scholars forming the so-called Claretus circle in the 1360s. These works were lexicographical and encyclopedic texts intended as learning aids and compiled in verse. They were written primarily for the purpose of providing students with Czech terminology for subjects that were taught at university in Latin. Crayfish are mentioned here in three different contexts.

First, in two of Claretus' works regarded as the oldest of this collection, we find crayfish in its astrological meaning as the name of the Zodiac sign for the month from mid-June to mid-July. In the Vocabularius, it is recorded in Latin as cancer and in Czech as "rakonow" (ClarVoc, line 296). This sign had also been known as rak or rakař in Czech since the mid-15th century (Hvezd, fol. 22v; SlovKlem, fol. 35r; TrojK, fol. 97r). The sign's detailed characteristics are described in Claretus' text Astronomicus, a work about astronomy and astrological prognostication, in a part dedicated to stars and the characteristics of children born under a particular sign (ClarAstr, lines 392-407). Crayfish also have been described in such Czech works as the dream book of Vavřinec (Laurentius) of Březová from the first half of the 15th century, which is itself based on an Arabic source (VavAstrol, p. 15-16). Here, crayfish is described as a cold, wet, and watery northern sign and people born under this sign are water-blooded (phlegmatic).

Second, we find crayfish mentioned in a medical context. The 14th century Latin text Medicaminarius describes the preparation of a medicine made of crayfish gastroliths (in Latin concha; ClarMed, lines 206-208: "pulvis cum melle coquatur de margaritis vel concha[s], que generatur in cancri capite"). These crayfish "stones" also penetrated medieval Latin-Czech dictionaries, as we find their definition in the Claretus' Glossary in Czech as "rakacz" (ClarGl, line 128 in the chapter on stones).

Medicine made use not only of gastroliths, but also of whole crayfish. Whether in compounds with a powder made from burnt crayfish (as in the anonymous Ms. NK I G 23, from 1415-1416, fol. 120r: "cum... pulveribus cancrorum fluvialium adustorum") or as boiled crayfish, which was a recommended part of the diet (for those suffering dropsy, see Ms. 
CapPr 1518, from 1434-1435). The 15th century brings the first mention in Czech of crayfish used for medicinal purposes (LekFr, fol. 66v). An unknown Franciscan emphasized the effectiveness of crayfish as medicine for gout, limb fractures, abortion, and cancer (LekFr, fol. 66v, 111-112r). Inasmuch as this medical book is surprisingly written in Old Czech instead of Latin, we can assume that the text was not meant only for well-educated physicians.

Returning to Claretus, the third context in which crayfish are mentioned is zoological. In Claretus' Glossary from 1365 and following it in some other dictionaries from the 14th and 15 th centuries the term rak is presented in the chapter dedicated to fish (or better said to aquatic animals) as a translation of the Latin word cancer (ClarGl, line 379).

It therefore seems that the Latin word cancer was understood in Bohemian sources as a reference to crayfish. This was not commonplace in Europe, since generally the Latin word cancer was used to denote different sorts of water animals, both from the sea and freshwater. In ancient times, particularly the freshwater crab (Greek karkinos, Latin cancer) was a creature frequently mentioned in folklore (Thompson, 1947).

Knowledge about crayfish was available to medieval students at universities through the Latin translation of Aristotle. Lexicographers, on the other hand, drew upon medieval encyclopedias. In Bohemia and Moravia during the Middle Ages an important available foreign source was Thomas Cantimpratensis' encyclopedia De natura rerum. This 13 th century encyclopedia has one passage dedicated to a group of animals designated as cancer. In addition to crayfish, this group also included crab, lobster, some crustaceans called miles (i.e. "soldier", in which, as Thomas wrote, no traces of meat or any other food are found, because it does not eat anything), and one crustacean, which was believed able to drag people underwater (ThomCant VII, 19). Cancer was a general designation for an animal with eight legs and claws. They moved backwards, but only when escaping, as otherwise they normally walk forward. When they got older, their heads contained two white stones with a touch of red. These stones were said to have the power of healing. Cancer animals eat oysters (in order for the oyster not to clap the cancer with its shell, the cancer did not remove the meat until it had propped open the shell with a small stone). When boiled, they became red. They hid in winter and in spring they changed their skin just as snakes do. Their lifespan was long. According to Thomas Cantimpratensis, if you fed them with milk they could survive many days out of water.

The aforementioned confusion between crab and crayfish is also evident in astrology. Within European regions in the Middle Ages, the crayfish replaced the crab as the symbol representing the sign "Cancer" (Swahn, 2004). This author also made a connection between crayfish's rising popularity as a Zodiac symbol and its use as a food source. This use as food is documented in Czech sources from the 15th and 16th centuries, as will be noted later. In contrast, in the previously mentioned medical book written by an unknown Franciscan from the 15 th century, the sign "Cancer" is symbolized by a crayfish, because the Sun returns in July just as a crayfish walks backwards (LekFr, fol. 148r). This confirms the assumption that the Latin word cancer was understood as representing either a crab or a crayfish, depending upon which animal was more frequent in the region in question - thus in Bohemia and Moravia as a crayfish.

As shown, the use of the Czech word rak to designate an animal is well documented since the 14th century. In a collection of proverbs dated from the late 14th century, crayfish were presented in two notes: a) "A kde rak, ješto vody nenie?" (And where is a crayfish when there is no water?), and b) "Nevždy rak na mlýně, někdy račice" (It's not always a male crayfish in the watermill, sometimes it's a female) (PrislFl, fol. 45r). Dictionaries also documented new terms for young crayfish: raczie in Old Czech and cancrio in Latin (ClarGl, line 398; and others, see SSL I, 512). For the sake of completeness, let us mention that the word rak together with the Latin cancer was used also for the disease cancer, in addition to such other terms as "rakovina", "podjed" (LekFr, fol. 111r), and "živý vlas" (CodVodn, fol. 118r).

The second half of the 14th century saw the first use of the Old Czech term for crayfish, rak, in the name of settlements in Bohemia and Moravia: the Moravian village "Rakodavy" from 1358 and the Bohemian village "Racowe" from 1368. These villages still exist today, but the name "Racowe" has transformed into "Raková". Many town and village names were related to crayfish in subsequent years, although their etymology is not always clear. Although the crayfish was not accepted as a regular heraldic figure, the great Hussite leader Jan Žižka from Trocnov (1360-1424) had on his coat of arms one red crayfish on a white shield (Sedláček, 2003). Krupauer (1968) noted crayfish or crayfish claws on the coats of arms of more than 10 minor Czech noble houses.

Crayfish is also documented in Latin sources as a house sign (in the Middle Ages there were no house numbers and people used to recognize houses according to the signs displayed above doors). In 15th-century Prague, there are records of the house "at the crayfish" ("Augustinum ab cancro"), the house "at the silver crayfish" ("Augustinum ab argenteo cancro"), the house "at the white crayfish" ("Augustino ab albo cancro"), the house "at the blue crayfish" ("domum... sitam exopposito cancri flavei"), and the house "at the red crayfish" ("domus cancri rubei"). These house names were later transferred to the people living there, and we therefore find the Latin word cancer and the Czech word rak in personal medieval names in sources from the 15th century (SSL I, 512).

All these facts testify to this animal's popularity in medieval Bohemia and Moravia. Furthermore, crayfish were probably commonly consumed by nobility, as Latin bills from the end of the 14th century for the kitchen belonging to a Czech lord show (Zíbrt, 2012).

\subsection{Modern Age}

The popularity of crayfish in human medicine continued into the Modern Age. In Bohemia and Moravia, three medical books (LekJB; LekJD; LekChir) were written in the early 16th century, but the authors are anonymous. These books contain 26 prescriptions for the use of crayfish against a wide spectrum of diseases and traumas (cancer, deafness, edema, urinary stones, gout, abscesses, rotting teeth, limb fractures, blood clotting, and exhaustion after illness) and also for arrow and bullet extractions. The aforementioned crayfish gastroliths, 
known as crayfish stones or lapides cancrorum, were applied under the eyelid to eliminate contaminants by initiating the flow of tears, and bags of crayfish stones were imported into Bohemia and Moravia from Russia (Krupauer, 1968). On the other hand, there was a widely accepted myth that a fly which sat on a dead crayfish might transmit cancer (the disease) (Krupauer, 1968).

The oldest known handwritten cookbook in Old Czech dating from the early 16th century (Paříková and Ciprová, 1995) compiled many recipes, from which three are focused on food prepared from crayfish: crayfish stew, spicy crayfish, and spicy crayfish with a raisin roux (KuchA, p. 72, 79, 96). The first printed cookbook in Old Czech was edited in 1542 and contains two recipes with crayfish: spicy crayfish and crayfish pudding (KuchB, fols. 69r-v). In 1591, alchemist Bavor Rodovský from Hustiřany within his residence at Budyně nad Ohří Castle wrote a cookbook including among other things one recipe for spicy crayfish (KuchRod, p. 265). Although these recipes are written in the language which use was generalized in the population and among social classes, there is no other evidence of crayfish consumption by poor inhabitants and recipes were most probably intended for the nobility. From this period, we have many records of crayfish consumption by aristocrats. In 1580, for example, 3600 crayfish were consumed at the wedding banquet of bon vivant and gourmet Petr Wok from Rosenberg (Pánek, 1989). In 1587, another member of this noble house, Wilhelm von Rosenberg, got married for the fourth time. Among the 100 guests was even Holy Roman Emperor Rudolph II. The pomp of the wedding banquet in the Rosenberg Palace was reminiscent of a royal wedding and the menu consisted of many foods including approximately 312000 boiled crayfish (Evans, 1973). Aside from the aforementioned celebrations, crayfish were eaten almost exclusively during Lent along with fish, waterfowl, turtles, frogs, and beavers (Beranová, 2005).

In the 16th century, vast majority of both lentic and lotic waters had been owned by nobility and monasteries. The first collections of capital punishments, known as "Smolné knihy" (black books or Acta negra maleficorum), were mandatorily written in this period of time. Although crayfish were probably not eaten by poor inhabitants, the black books included crayfish poaching among the crime leading to death penalties. Arrested poachers had to pay a fine of 600 Prague groschens (Grossi Pragenses), approximately the price of 600 loaves of bread. If the price of the captured crayfish was higher or the poacher was insolvent, he was immediately executed (KristPrav, p. 308, 578). In 1573, Kašpar Šwancz from Lhota, who had poached trouts and crayfish and sold them to the pastor Melichar in Chvaleč, was convicted and hanged for this reason in the town of Stárkov (northeastern Bohemia); no penalty for the pastor was recorded (Stark, pp. 3-5). In 1577, also in this town, two crayfish poachers named Jan from Libňatov and his servant Vondra Černý from Úpice were interrogated by a court. After torture, they confessed to having captured crayfish several nights in sacks baited with roasted frog meat; the crayfish were subsequently supplied to aldermen of Hradec Králové and one threescore of crayfish was sold for three groschens. Both poachers were sentenced to execution by hanging (Stark, p. 5-7). From these records, it follows that crayfish were mainly supplied to the kitchens of clergymen and rich townsfolk.

Two cookbooks are known from Bohemia and Moravia from the 17th century. Both of them are written in Old Czech and it is emphasized that the recipes are designated for aristocratic kitchens. The first book is dated from 1645 and contains a recipe for chicken stuffed with crayfish meat. The dating of the second one is unclear, and we can only state that this book was written in the first half of the 17th century. It described in detail four recipes with crayfish: crayfish cake, crayfish donuts, crayfish with sauce, and fried crayfish (Paříková and Ciprová, 1995). Beranová (2005) mentioned one recipe from the 17th century for crayfish meat served in oyster shells as false oysters. Crayfish was mentioned more frequently in the 18th century in such other cookbooks as Kniha kuchařská Kateřiny Koniášové from 1712 (Zíbrt, 2012).

\subsection{Contemporary Age}

In 1826, crayfish were mentioned along with fish, snails, mussels, turtles, and frogs as Lenten food in a very popular belletristic cookbook (Rettigová, 1826). Frič and Nekut in 1868 published the first scientific work focused on crustaceans, including crayfish, in Bohemia and Moravia. The first new species of crayfish, Astacus leptodactylus, was introduced from Eastern Europe to Bohemia and later Moravia at the end of the 19th century (ca 1890) in order to replenish declining populations of indigenous A. astacus (Petrusek et al., 2006). Although there is no evidence as to the quantity of crayfish exploited in the 19th century, they were listed under Section 1 of Law 62/1895 mor. z. z. (Moravian regional code of law) as an animal attractive and allowed for aquaculture farming (Soukup, 1955). Around 1860, an occurrence of crayfish plague was first recorded in Europe (Söderhäll and Cerenius, 1999). The source of the pathogen is not known but it might have been introduced via ships' ballast water with infected North American crayfish (Holdich, 2003). The crayfish plague induced a decline in indigenous crayfish populations (e.g. Alderman, 1996; Petrusek et al., 2006; Kozubíková et al., 2008) throughout continental Europe. This disease was first recognized in Bohemia in 1879 and in Moravia in about 1902; between 1898 and 1902, massive mortality of indigenous crayfish was recorded for this reason (Votrubec, 1931).

At the turn of the 19th century, crayfish farming was evidently well known in the region, because Scribani (1894, 1902) and Otto (1904) described in detail pond astaciculture (i.e. the sector of aquaculture focused especially on crayfish). Otto (1904) emphasized, however, that this type of farming was not profitable and could only be used to keep females with eggs and breed juveniles, which he recommended be released at adulthood into brooks with unpolluted water (and not necessarily in the vicinity of where the juvenile crayfish had hatched). Therefore, this note provides the first known evidence of potential crayfish translocation to new locations in Moravia and Bohemia. In this year (1904), 468 crayfishing grounds were registered across the two regions (238 in Bohemia, 230 in Moravia) and 47129 individuals of A. astacus (20 877 in Bohemia, 26252 in Moravia) were exported for 
consumption abroad (Mokrý, 1935; Krupauer, 1968). Astaciculture methods were improved in subsequent years and crayfish were exported fresh as well as canned (Votrubec, 1931).

Václav Josef Štěpán established the High School of Fishery in Vodňany in 1920 and the curriculum consisted of specialized subjects that included crayfish breeding (e.g. Berka, 2006). Human crayfish consumption was emphasized in many publications from this period (e.g. Posnerová, 1918; Votrubec, 1931). Daněk (1933) noted that crayfish, commonly captured for consumption, faced decline in abundance in the wild due to intensive harvesting, water pollution, and spread of infectious diseases. The crayfish capture was prohibited from 1 November to 30 June in Bohemia (capture of females carrying eggs was prohibited over the entire season) and from 15 October to 15 May for males in Moravia (capture of all crayfish females was prohibited over the entire season) since 1883. The minimum total body length (TL) for captured crayfish was $12 \mathrm{~cm}$ in Bohemia and $10 \mathrm{~cm}$ in Moravia (Votrubec, 1931). Teplý (1937) noted that captured crayfish were sorted by " $v r h$ " (3 individuals) and "mandel" (15 individuals). Crayfish were evidently produced in commercial breeding (most probably in pond astaciculture) at that time, because stocks of young crayfish were advertised by fishery associations, with the price of one young crayfish (20 hellers) approximately equivalent to one-tenth the price of a loaf of bread (RybV, p. 184). Similarly as in Poland, the price for crayfish $15 \mathrm{~cm}$ in TL was approximately five times higher than that for individuals $10 \mathrm{~cm}$ in TL (Gajewski and Terlecki, 1956).

Although populations of indigenous crayfish species were constantly declining, A. astacus was still listed as an animal that could be legally exploited by fisheries. This fact is recorded in Section 2 of Law 62/1952. During this time, capture and trapping of crayfish were prohibited between the beginning of October and the end of the April in both territories. Capture of females with eggs was prohibited over the whole season. The minimum TL of captured crayfish was $13 \mathrm{~cm}$ and one hunter was not allowed to capture more than 30 crayfish. Permitted crayfish capture methods involved various types of nets, cages, and angling on fishing lines (Šimek, 1959). The biology, ecology, distribution, diseases, predators, and exploitation of indigenous species of crayfish in Bohemia and Moravia were summarized by Krupauer (1968). Crayfish were exported abroad from the region by the Foreign Trade Agency (Prague, Czechoslovakia), and particularly to France (Kozák, 2014, personal communication, November 12, 2014), until the end of 1970s (Krupauer, 1980).

In the 1960s, the North American crayfish O. limosus most probably expanded into Bohemia spontaneously from Germany and quickly inhabited the Elbe River basin (Petrusek et al., 2006). This species was recently recorded also in Oder River basin near Moravia (Ďuriš and Horká, 2007). In the 1980s, a third new crayfish species was introduced to the region. The North American crayfish P. leniusculus was imported from Sweden for aquaculture purposes (Kozák and Policar, 2003; Petrusek et al., 2006). Subsequently, a crayfish plague transmitted by both these species rapidly decimated the already weakened populations of indigenous crayfish and this unfortunately remains a threat to this day (Kozubíková et al., 2008).
In the second half of the 20th century and in early $21 \mathrm{st}$ century, in association with the decline in indigenous crayfish abundance, the availability and subsequent popularity of crayfish-meat consumption fell and crayfish began to be perceived by most people as a very rare animal (e.g. Krupauer, 1980). Indigenous crayfish species are protected by laws in many European countries, including the Czech Republic (e.g. Peay, 2009; Patoka et al., 2014b). In the 21st century, new species in the wild have been recognized in numerous European countries (Kouba et al., 2014). Monitoring of both indigenous and nonindigenous crayfish species began in 1986 (e.g. Patoka et al., 2014c), and certain Czech research institutions have investigated crayfish biology, ecology, and ethology. Kozák et al. (2013) recently published scientific insight into crayfish biology and breeding in a Czech-language book. The book was subsequently translated into English (Kozák et al., 2015).

The popularity of crayfish consumption in the region is once again on the rise. Imported frozen crayfish tails and live crayfish are promoted in grocery shops. The vast majority of crayfish imported for consumption purposes is of the North American species Procambarus clarkii (Girard) and are produced on farms abroad, mainly in China. With the single exception of the small-scale farm Jotra s.r.o. (Nová Pec, south Bohemia), there are presently no records of commercial crayfish production from aquaculture in the region.

Different situation exists in the pet trade with estimated annual domestic production around 60-100 thousands ornamental crayfish (Patoka et al., 2015a). Pet trade in crayfish began in the Czech Republic in 2003 (Patoka et al., 2015a). The keeping of ornamental crayfish in aquaria has been accompanied by certain pet-breeder handbooks written in Czech (Patoka, 2008, 2013). Complete lists of ornamental crayfish species traded in the Czech Republic, their imported quantities and prices with trend predictions have been published (Patoka et al., 2014b, 2015a) and some new species were scientifically described in this regard (Patoka et al., 2015b,c). Risk assessment and potential invasiveness of ornamental crayfish species were highlighted by Patoka et al. (2014b). At least two of most traded ornamental crayfish in the country, $P$. clarkii and $P$. fallax $\mathrm{f}$. virginalis have the ability to withstand low winter temperatures relevant for lentic habitats in the European temperate zone (Veselý et al., 2015). Unfortunately, legislation needed to reduce this threat for native biota is generally nonexistent. With about 30 advertised species, the Czech Republic is the secondlargest market for ornamental crayfish in Europe (Patoka et al., 2014b; Faulkes, 2015). The international pet trade in these animals should therefore not be overlooked in the future, and its monitoring has been recommended (Patoka et al., 2014b, 2014d, 2015a).

\subsection{Implication for the future}

There exist positive or negative attitudes towards different animals (Campbell and Lancaster, 2010; Schlegel and Rupf 2010), but, as a non-stereotypically charismatic animal, crayfish is generally seen by people within the Czech cultural space in a positive light (e.g. Krupauer, 1968). As a current anecdotal 


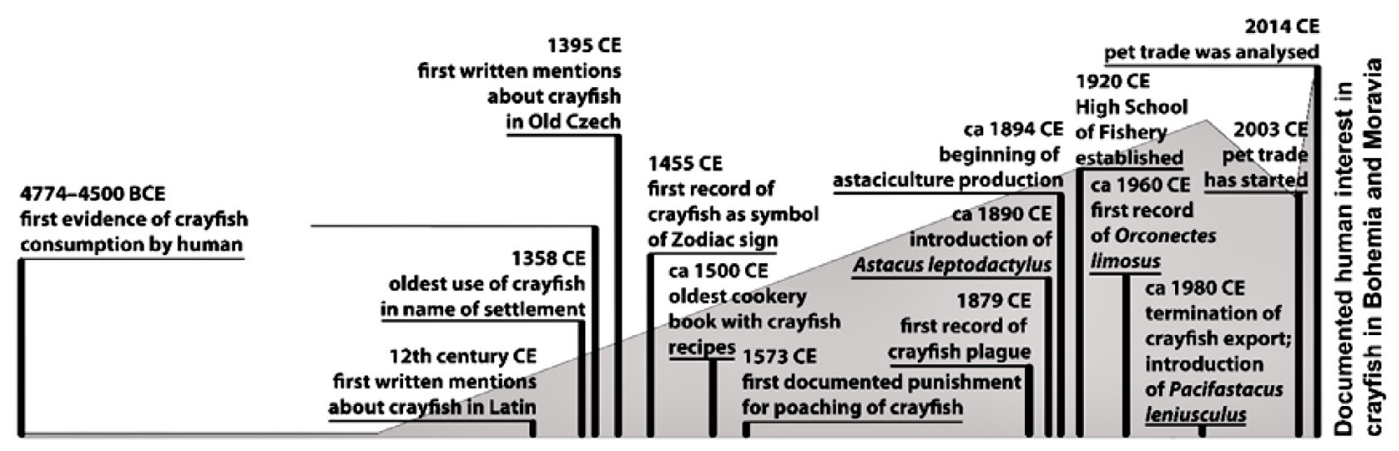

$\begin{array}{lllll}\text { Prehistory } & \text { Ancient Age } & \text { Middle Age } & \text { Modern Age } & \text { Contemporary Age }\end{array}$

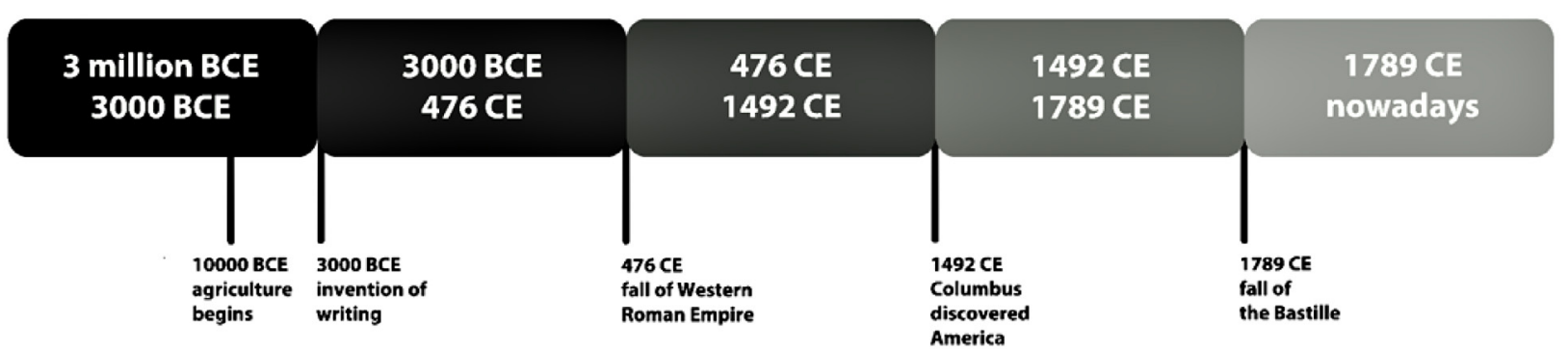

Fig. 1. Timeline of documented human interest in crayfish in Bohemia and Moravia from Prehistory to the present; important moments are highlighted. The gray shade indicates an estimation of popularity of crayfish.

example, the crayfish are famous from the very popular cartoon Jak krtek ke kalhotkám prišel (How Little Mole Got His Trousers) (Petiška and Miler, 1986), and people in the region know this animal from their childhood. But due to the 'modern way of life' and human isolation from nature, these animals are perceived by many people as a fabled creature of the past. As the present study showed for a long historical period this was not the case.

We may expect that the increasing popularity of keeping freshwater crayfish as pets will continue in near future. It is evident by growing numbers of their imports within the pet trade (Patoka et al., 2015a). Many locations in Bohemia are meanwhile being invaded by the non-native $O$ limosus, a crayfish species with daytime activity. That situation will increase the possibility of its encounter with the general public, which might pique public curiosity about crayfish. Paradoxically, the rising interest also heightens risk to native crayfish through the possible translocation of both native and non-native crayfish or the release of ornamental crayfish from the pet trade. The problem lies in society's insufficient perceptions as to the importance of native crayfish conservation, and this has caused the plight of native crayfish populations in Bohemia and Moravia. This view is supported by findings reported in previous publications (e.g. Patoka et al., 2014d).

Activities directed to protecting endangered indigenous crayfish species are undertaken mainly by conservationists, while much smaller contributions come from fishermen and wildlife managers. This is consistent with the findings of Van Dooren (2014), who expressed concern that extinction is not a popular topic today. The legal restrictions seem to be ineffective, because these have been in force since the second half of the 20th century and the deteriorating situation has not much changed (Kozák et al., 2013).

Native crayfish species have the potential to arouse interest in conservation among the inhabitants of Bohemia and Moravia. Raising such interest should be a key factor in the effective care of endangered crayfish, because this greatly depends on the general public's awareness and attitudes (Fischer et al., 2011). Moreover, the perception of crayfish as an iconic animal may play an important role in conservation efforts. Both historical records and present-day references to crayfish show that it was and still is perceived in this way (e.g. coats of arms, fairy tales, house signs, and so on).

Unfortunately, the general public does not clearly recognize native versus non-native species of crayfish, and thus much more needs to be done to highlight how correctly to determine and differentiate crayfish species occurring in Bohemia and Moravia (Štambergová et al., 2009). Within the region, endangered crayfish have the potential to acquire new value as an umbrella species for conservation, especially in relation to associated species which are also endangered but which do not have merit as iconic animals for humans. Therefore, the promotion and improvement of awareness and effective care of endangered crayfish may also be positively reflected in conservation of their habitat as a whole.

\section{Conclusion}

Crayfish have been exploited for many purposes from prehistory to the present on the territory of Bohemia and Moravia (Figure 1). Crayfish were primordially captured for consumption already in the Neolithic times, but there is a long period from antiquity to the Middle Ages during which there is no evidence of a relationship between humans and crayfish. Many 
written notes from the Middle Ages documented successively increasing interest in crayfish for consumption as well as for medicinal purposes. Crayfish were eaten mainly by the nobility, and in the beginning of the 19th century they became popular among the general public. With the decline in indigenous species abundance, crayfish consumption ceased in the second half of the 20th century. In recent years, however, import of ornamental crayfish for keeping in aquaria has begun and imported crayfish meat has become a popular delicacy. The long history of the relationship between crayfish and humans in Bohemia and Moravia thus continues. This paper presents deep insight into the importance of crayfish for people within the Czech cultural space, and thus it provides stakeholders detailed information from a perspective useful for conservation management and propagation of endangered crayfish species.

Acknowledgements. We are grateful to Pavel Kozák for his helpful information. This study was supported by the CIGA Project No. 20152007, and by a research project of the Institute of Philosophy of the Czech Academy of Sciences (RVO: 67985955). The proofreading of English was conducted by English Editorial Services, s.r.o.

\section{Abbreviations}

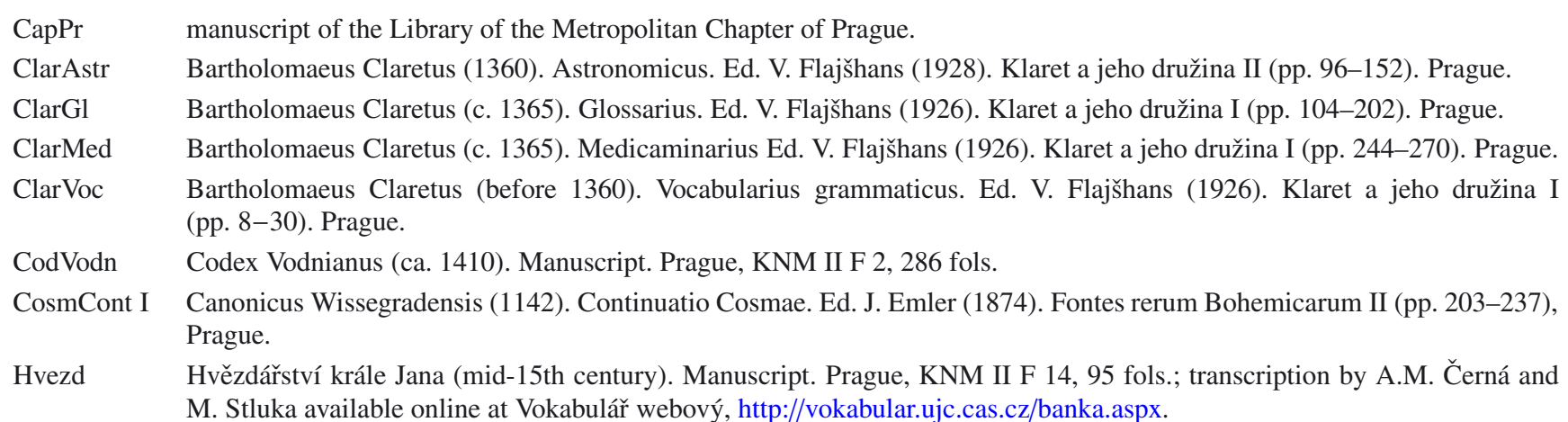

KNM manuscript of the Library of the National Museum of Prague.

KristPrav Pavel Kristián z Koldína (1579). Práva městská Království českého. Ed. Malý, K., Slavíčková, P., Soukup, L., Skřejpková, P., Šouša, J., Vojtíšková, J., \& Woitschová, K. (2013). Prague: Karolinum.

KuchA Kuchařka (1490-1520). Manuscript. Prague, KNM I H 51, Ed. Zíbrt, Č. (2012) Staročeské umění kuchařské (pp. 71-98) Prague: Dauphin

KuchB Kuchařka (1542 or after). Prague, NK 54.K.22940; 108 fols.

KuchRod Bavor Rodovský z Hustiřan (1591). Kuchařství to jest knížka o rozličných krmích, kterak se užitečně s chutí strojiti mají. Ed. Zíbrt, Č. (2012) Staročeské umění kuchařské (pp. 217-299). Prague: Dauphin.

LekChir Chirurgické lékařství (early 16th century). Manuscript. Prague, NK XVII H 23; 343 fols.; transcription by A.M. Černá available online at Vokabulář webový, http://vokabular.ujc.cas.cz/banka.aspx.

LekFr Lékařství neznámého františkána (mid-15th century). Manuscript. Prague, NK XVII B 18, fols. 1r-173v; transcription by A.M. Černá available online at Vokabulář webový, http://vokabular.ujc.cas.cz/banka.aspx.

LekJB Knihy lékařské (1502-1503). Manuscript. Moravská zemská knihovna Brno 156, 168 fols.; transcription by A. M. Černá available online at Vokabulář webový, http://vokabular.ujc.cas.cz/banka.aspx.

LekJD Jádro lékařské (1518). Manuscript. Prague, KNM I F 11, 369 pp; transcription by A. M. Černá available online at Vokabulár webový, http://vokabular.ujc.cas.cz/banka.aspx.

NK manuscript of the National Library of Prague

PrislFl Sbírka přísloví připisovaná Smilu Flaškovi z Pardubic (end of the 14th century). Manuscript. A 4, Státní oblastní archiv Třeboň, fols. 42r-46v; transcription by A. Zitová \& A. M. Černá available online at Vokabulář webový, http://vokabular. ujc.cas.cz/banka.aspx.

RybV Rybářský Věstník (1938). Vol. 18(9). Prague: Orgán rybářské unie Československé republiky.

SlovKlem Slovník Klementinský (1455). Manuscript. Prague, NK XVII F 31, fols. 1r-91v; transcription by K. Voleková available online at Vokabulář webový, http://vokabular.ujc.cas.cz/banka.aspx.

Stark Knihy černé jinak smolné městečka Stárkova z let 1573-1799 (book 11). Stárkov: Archiv města Stárkov. Deposited at SOkA Náchod.

SSL Slovník středověké latiny v českých zemích (Latinitatis medii aevi lexicon Bohemorum) (1977-1977). Prague.

ThomCant Thomas Cantimpratensis (13th century). Liber de natura rerum. Ed. H. Boese (1973), (pp. 431). Berlin, New York.

TrojK Kronika trojánská (1469). Manuscript. Prague, NK XVII B 6, fols. 78r-172v; transcription by P. Kuderová available online at Vokabulář webový, http://vokabular.ujc.cas.cz/banka.aspx.

VavAstrol Vavřinec z Březové (before 1437). Astrologie ze Snáře. Manuscript. Brno, Moravský zemský archiv, sign. G 10, č. 461 (from the year 1471), (pp. 14-35); transcription by A. M. Černá available online at Vokabulář webový, http://vokabular.ujc. cas.cz/banka.aspx. 


\section{References}

Alderman D.J., 1996. Geographical spread of bacterial and fungal diseases of crustaceans. Rev. Sci. Tech. OIE, 15, 603-632.

Beranová M., 2005. Jídlo a pití v pravěku a ve stř̌edověku. Academia, Prague.

Berka R., 2006. Kdo byl kdo v českém a moravském rybářství. Rybářské sdružení ČR, České Budějovice.

Campbell M. and Lancaster B.L., 2010. Public attitudes toward black bears (Ursus americanus) and cougars (Puma concolor) on Vancouver Island. Soc. Anim., 18, 40-57.

Clavero M., Nores C., Kubersky-Piredda S. and Centeno-Cuadros, A., 2015. Interdisciplinarity to reconstruct historical introductions: solving the status of cryptogenic crayfish. Biol. Rev., DOI: 10.1111/brv.12205.

Daněk G., 1933. Zoologie pro střední školy. Československá grafická unie, Prague.

Ďuriš Z. and Horká I., 2007. First record of the invasive spinycheek crayfish Orconectes limosus (Rafinesque) in Moravian and Silesian region, Czech Republic. Časopis Slezského Muzea A, 56, 49-52.

Dvorak V., Hladny J. and Kasparek L., 1997. Climate change hydrology and water resources impact and adaptation for selected river basins in the Czech Republic. Clim. Change, 36, 93-106.

Evans R.J.W., 1973. Rudolf II and his world: a study in intellectual history, Clarendon Press, Oxford, pp. 1576-1612.

Faulkes Z., 2015. Marmorkrebs (Procambarus fallax f. virginalis) are the most popular crayfish in the North American pet trade. Knowl. Manag. Aquat. Ecosyst., 416, 20.

Fischer A., Bednar-Friedl B., Langers F., Dobrovodská M., Geamana N., Skogen K. and Dumortier M., 2011. Universal criteria for species conservation priorities? Findings from a survey of public views across Europe. Biol. Conserv., 144, 998-1007.

Frič A. and Nekut F., 1868. Korýši země české. Grégr, Prague.

Gajewski Z. and Terlecki W., 1956. Raki. Państwowe wydawnictwo rolniczne i leśne, Warsaw.

Holdich D.M., 2003. Crayfish in Europe - an overview of taxonomy, legislation, distribution, and crayfish plague outbreaks. In: Holdich D.M. and Sibley P.J. (eds.), Management \& conservation of crayfish: Proceedings of a conference held on 7th November, 2002, Environment Agency, Bristol, 15-34.

Holdich D.M., Reynolds J.D., Souty-Grosset C. and Sibley P.J., 2009. A review of the ever increasing threat to European crayfish from non-indigenous crayfish species. Knowl. Manag. Aquat. Ecosyst., 394-395, 11.

Kouba A., Petrusek A. and Kozák P., 2014. Continental-wide distribution of crayfish species in Europe: update and maps. Knowl. Manag. Aquat. Ecosyst., 413, 05.

Koutrakis E., Machino Y., Mylona D. and Perdikaris C., 2009. Crayfish terminology in ancient Greek, Latin, and other European languages. Crustaceana, 82, 1535-1546.

Kozák P. and Policar T., 2003. Practical elimination of signal crayfish, Pacifastacus leniusculus (Dana), from a pond. In: Holdich D.M. and Sibley P.J. (eds.), Management \& conservation of crayfish: Proceedings of a conference held on 7th November, 2002, Environment Agency, Bristol, 200-208.

Kozák P., Ďuriš Z., Petrusek A., Buřič M., Horká I., Kouba A., Kozubíková E. and Policar T., 2013. Biologie a chov raků. University of South Bohemia in České Budějovice, Vodńany.

Kozák P., Duuriš Z., Petrusek A., Buřič M., Horká I., Kouba A., Kozubíková-Balcarová E. and Policar T., 2015. Crayfish biology and culture. University of South Bohemia in České Budějovice, Vodńany.
Kozubíková E., Petrusek A., Ďuriš Z., Martín M.P., DiéguezUribeondo J. and Oidtmann B., 2008. The old menace is back: recent crayfish plague outbreaks in the Czech Republic. Aquaculture, 274, 208-217.

Kozubíková-Balcarová E., Beran L., Ďuriš Z., Fischer D., Horká I., Svobodová J. and Petrusek A., 2014. Status and recovery of indigenous crayfish populations after recent crayfish plague outbreaks in the Czech Republic. Ethol. Ecol. Evol., 26, 299-319.

Krupauer V., 1968. Zlatý rak. Nakladatelství České Budějovice, České Budějovice.

Krupauer V., 1980. Raci. Český rybářský svaz, Prague.

Mokrý T., 1935. Hospodářství rybniční. František Podhajský, Písek.

Otto J., 1904. Ottův slovník naučný. J. Otto, Prague, Vol. 21.

Pánek J., 1989. Poslední Rožmberkové - Velmoži České renesance. Panorama, Prague.

Pánek J. and Tůma O., 2009. A history of the Czech lands. Karolinum Press, Charles University, Prague.

Paříková M. and Ciprová I., 1995. Dobrá kuchařka českých šlechticů a měšt'anů od gotiky po baroko. Avatar, Prague.

Patoka J., 2008. Chováme sladkovodní raky. Grada Publishing, Prague.

Patoka J., 2013. Sladkovodní raci. Robimaus, Rudná u Prahy.

Patoka J., Nývltová Fišáková M., Kalous L., Škrdla P. and Kuča, M., 2014a. Earliest evidence for human consumption of crayfish. Crustaceana, 87, 1578-1585.

Patoka J., Kalous L. and Kopecký O., 2014b. Risk assessment of the crayfish pet trade based on data from the Czech Republic. Biol. Invasions, 16, 2489-2494.

Patoka J., Bláha M. and Kouba A., 2015c. Cherax (Cherax) subterigneus, a new crayfish (Decapoda: Parastacidae) from West Papua, Indonesia. J. Crustacean Biol., 35, 830-838.

Patoka J., Kalous L. and Petrtýl M., 2014c. Size and structure of an isolated adult noble crayfish population. Workshop on Biodiversity, Jevany, 6, 157-161.

Patoka J., Petrtýl M. and Kalous L., 2014d. Garden ponds as potential introduction pathway of ornamental crayfish. Knowl. Manag. Aquat. Ecosyst., 414, 13.

Patoka J., Kalous L. and Kopecký O., 2015a. Imports of ornamental crayfish: the first decade from the Czech Republic's perspective. Knowl. Manag. Aquat. Ecosyst., 416, 04.

Patoka J., Bláha M. and Kouba A., 2015b. Cherax (Astaconephrops) gherardii, a new crayfish (Decapoda: Parastacidae) from West Papua, Indonesia. Zootaxa, 3964, 526-536.

Peay S., 2009. Invasive non-indigenous crayfish species in Europe: recommendations on managing them. Knowl. Manag. Aquat. Ecosyst., 394-395, 03.

Petiška E. and Miler Z., 2001. Jak krtek ke kalhotkám přišel. Albatros, Prague.

Petrusek A., Filipová L., Ďuriš Z., Horká I., Kozák P., Policar T., Štambergová M. and Kučera Z., 2006. Distribution of the invasive spiny-cheek crayfish (Orconectes limosus) in the Czech Republic. Past and present. Bull. Fr. Pêche Piscic., 380-381, 903-918.

Posnerová I., 1918. Polévky a omáčky. A. Neubert, Prague.

Rettigová M.D., 1826. Domácí kuchařka. Josef Pospíšil, Prague.

Schlegel J. and Rupf R., 2010. Attitudes towards potential animal flagship species in nature conservation: a survey among students of different educational institutions. J. Nat. Conserv., 18, 278-290.

Scribani A., 1894. Rak a jeho chov. Scribani, Německý Brod.

Scribani A., 1902. Návod, kterak možno docíliti rozmnožení raků ve vodách vysočiny českomoravské. Spisovatel, Německý Brod. 
Sedláček A., 2003. Atlasy erbů a pečetí české a moravské středověké šlechty. Academia, Prague, Vol. 5.

Söderhäll K. and Cerenius L., 1999. The crayfish plague fungus: History and recent advances. Freshwater Crayfish, 12, $11-35$.

Soukup T., 1955. Zákon o rybářství. Nakladatelství Orbis, Prague.

Šimek Z., 1959. Rybářství na tekoucích vodách. Státní Zemědělské Nakladatelství, Prague.

Štambergová M., Svobodová J. and Kozubíková E. 2009. Raci v České republice. Agentura ochrany přírody a krajiny ČR, Prague. Swahn J.Ö., 2004. The cultural history of crayfish. Bull. Fr. Pêche Piscic., 372-373, 243-251.
Teplý F., 1937. Příspěvky k dějinám českého rybářství. Ministerstvo zemědělství, Prague.

Thompson D'A.W., 1947. A Glossary of Greek Fishes. Oxford University Press, London.

Van Dooren T., 2014. Flight ways: Life and loss at the edge of extinction. Columbia University Press, New York.

Veselý L., Buřič M., Kouba A., 2015. Hardy exotics species in temperate zone: can "warm water" crayfish invaders establish regardless of low temperatures? Sci. Rep., DOI: 10.1038/srep16340.

Votrubec J., 1931. Chov raků a velevruba perlonosného. Ministerstvo zemědělství, Prague.

Zíbrt Č. 2012 Staročeské umění kuchařské. Dauphin, Prague.

Cite this article as: J. Patoka, B. Kocánová and L. Kalous, 2016. Crayfish in Czech cultural space: the longest documented relationship between humans and crayfish in Europe. Knowl. Manag. Aquat. Ecosyst., 417, 5. 